\title{
PENALARAN MORAL ANAK DITINJAU DARI GAYA PENGASUHAN DAN JENIS KELAMIN
}

\section{Nurhayani *}

*UIN Sumatera Utara

DOI: https://doi.org/10.21009/JPPP.071.04

\author{
Alamat Korespondensi: \\ hayani1976@gmail.com
}

\begin{abstract}
The objectives of this research is to know the difference of moral reasoning between boys and girls perceived from authoritarian, authoritative and permissive parents. The subjects of this research were 81 students at primary school of Al Falah Sei Mencirim Kutalimbaru Sumatera Utara. The data of the study was collected by using two scales, they are Moral Reasoning scale and parenting style scale. Analysis of Variance (ANOVA) was applied to analyze the data, which resulted that parenting styles and gender interact each other in affecting moral reasoning $(F: 5,580 ; p=0.006<0.05)$, and it means that there is a difference of moral reasoning among boys and girls perceived from authoritarian, authoritative and permissive parenting styles. Based on the finding above, it is suggested that educators should develop suitable teaching strategy which may enhance positive developmental aspects by avoiding sex stereotypes; encouraging to be independent and take a risk; and guiding in problem solving. It is suggested too that parents should avoid different parenting between boys and girls and help them to make moral decision properly so the can avoid social adapting problems.
\end{abstract}

\section{Keywords}

Moral reasoning, parenting style, gender

\section{Pendahuluan}

Keterbukaan informasi saat ini telah membuat anak merespon segala hal yang diberikan dalam bentuk kemampuan berfikir anak dalam mengambil keputusan untuk berbuat baik atau buruk. Namun setiap anak memiliki kemampuan yang berbeda di dalam menyikapi suatu masalah berdasarkan kapasitas intelektual yang dimiliki. Ketika berhadapan dengan masalah yang kompleks anak akan menanggapi masalah yang dihadapi sesuai tingkatan mana masalah itu dapat difahaminya.

Perkembangan moral yang baik pada anak tidak bisa tercapai secara instan dan dipercepat karena perkembangan moral anak memang harus melalui tahapan perkembangan. Anak harus diajarkan moral sesuai tahap perkembangannya untuk mampu membawa diri mereka sendiri untuk berbuat baik.

Dalam mengajarkan nilai moral, ada anak yang menanggapi dengan sikap skeptis dan kritis, cepat bosan, terpaksa dan ada yang mempertahankan pendapatnya, sensitif, kurang tenggang rasa dan tidak mudah tunduk terhadap tekanan, semuanya dapat menjadi penyebab ketidakmampuan anak memahami dirinya yang dapat berakhir dengan munculnya perasaan ditolak atau kurang 
dimengerti oleh lingkungannya. Kepekaan perasaan ini mengarahkan anak untuk mempersepsi sinyal-sinyal sosial secara tidak tepat sehingga berpengaruh guna berfungsinya pemikiran moral untuk berperilaku sesuai situasi sosial.

Ketidakmampuan anak di dalam memahami dirinya untuk berperilaku sesuai nilai moral terjadi karena anak belum dapat mengkonstruksikan dan memfungsikan kognisi sosial dengan efektif dan rasional maka adanya bimbingan dan dukungan dari orangtua sangat diperlukan anak untuk memperbaiki setiap keburukan yang mereka perbuat sebagai tanda keberhasilan pendidikan moralnya.

Penalaran moral disebut juga dengan istilah moral reasoning, moral thinking dan moral judgement adalah suatu pemikiran tentang masalah moral sebagai prinsip yang dipakai dalam menilai dan melakukan suatu tindakan dalam situasi moral (Kohlberg, 1981). Penalaran moral bukanlah pada apa yang baik atau yang buruk, tetapi pada bagaimana seseorang berpikir sampai pada keputusan bahwa sesuatu adalah baik atau buruk. Penalaran-penalaran moral inilah yang menjadi indikator dari tingkatan atau tahap kematangan moral.

Seorang anak memerlukan suatu pengetahuan dengan memasukkan informasi, gagasan-gagasan dan nilai-nilai dari luar dirinya yang kemudian diolah dalam pemikiran anak menjadi suatu konsep, paradigma atau cara pandang terhadap nilai moral untuk membentuk suatu perilaku moral.

Orang tua menyajikan panduan yang diinternalisasi sehingga anak-anak berperilaku mengacu nilai-nilai, bahkan ketika otoritas eksternal tidak berada di sisi anak-anak untuk mengawasinya. Konsep internalisasi digunakan untuk menjelaskan bagaimana individu menjadi pengendali atas perilaku moral sendiri dengan menerima nilai-nilai moral yang diadopsi sebagai miliknya yang akan membimbing tindakannya. Pengendalian yang semula dilakukan orang lain digantikan dengan pengendalian oleh diri sendiri (Hoffman dalam Staumb, 1978).
Anak belajar memahami nilai-nilai moral dari observasi dan meniru orang dewasa. Menurut Barlow (dalam Syah, 2000) sebagian besar dari yang dipelajari manusia terjadi melalui peniruan (imitation) dan penyajian contoh perilaku (modelling). Dalam hal ini, seorang anak belajar mengubah perilakunya sendiri melalui penyaksian atau melihat cara orang atau sekelompok orang mereaksi atau merespon sebuah stimulus tertentu. Anak juga dapat mempelajari respon-respons baru dengan cara pengamatan terhadap contoh perilaku dari orang lain, terutama terhadap orang tuanya.

Gilligan \& Wiggins dalam Hoffman 1994) mengemukakan bahwa pengalaman perasaan empati penting dalam perkembangan pemahaman moral. Penjelasan dari orang tua pada anak mengenai apa yang menyebabkan rasa tertekan yang dialami orang lain khususnya jika disertai dengan komponen afektif yang kuat akan efektif dapat mendorong perilaku altruisme (mendahulukan kepentingan orang lain) pada anak.

Kohlberg (1995) menjelaskan bahwa ada perbedaan tahap penalaran moral antara anak laki-laki dan anak perempuan yang diasumsikan bahwa penalaran moral anak laki-laki lebih tinggi dari penalaran moral anak perempuan yaitu anak laki-laki berada pada tahap empat sedangkan anak perempuan berada pada tahap tiga.

\section{Tujuan Penelitian}

Penelitian ini bertujuan untuk mengetahui perbedaan penalaran moral antara anak yang memperoleh gaya pengasuhan otoriter, otoritatif dan permissif usia sekolah dasar, peran gaya pengasuhan ayah dan ibu sebagai figur identifikasi perilaku moral pada anak sehingga dapat diketahui bagaimana perbedaan keputusan moral pada anak lakilaki dan perempuan.

\section{Metode Pengumpulan Data}

Metode pengumpulan data yang digunakan dalam kegiatan penelitian bertujuan untuk mengumpulkan data yang akurat dari variabel yang diteliti. Pada penelitian ini metode pengumpulan data menggunakan metode skala. Menurut Suryabrata (1990), skala merupakan metode 
penelitian yang menggunakan daftar pernyataan yang harus dijawab atau daftar isian yang harus diisi oleh sejumlah subjek dan berdasarkan atas jawaban atau isian tersebut, penyelidik mengambil kesimpulan mengenai subjek yang diselidiki. Alat pengumpulan data yang digunakan dalam penelitian ini terdiri dari:

\section{1) Skala Keputusan Moral Anak}

Variabel akan diungkap dengan skala penalaran moral anak. Skala ini mengukur sepuluh aspek moral dasar yaitu aspek kejujuran, adil, keteguhan hati, pemaaf, kesetiaan, menghargai, tanggung jawab, kerja sama, empati, dan suka menolong/berbagi. Masing-masing aspek dijabarkan menjadi aitem positif dan negatif. Skala ini terdiri dari 30 aitem yang terdiri dari 19 aitem favourable dan 11 aitem unfavourable,

2) Skala Gaya Pengasuhan

Skala gaya pengasuhan ini dimaksudkan untuk mengumpulkan data tentang gaya pengasuhan yang diterapkan orangtua menurut persepsi anak. Penelitian ini menggunakan skala gaya pengasuhan anak yang disusun oleh Yuniarti (1988 dalam Azwar 2003). Skala ini terdiri dari 30 aitem dengan lima alternatif jawaban.

Berdasarkan Hasil Uji Validitas dan Reliabilitas, pada skala penalaran moral pada anak terdiri dari 30 butir dan terbagi dalam 10 aspek. Hasil analisis butir didapatkan dari $r$ hitung $>\mathrm{r}$ tabel untuk $\mathrm{N}$ 81 : 0.1498. Reliabilitas alat ukur diuji dengan menggunakan Program Uji Keandalan teknik Alpha Cronbach dari program statistik SPSS versi 11,00. Berdasarkan uji validitas aitem, maka dapat diketahui jumlah aitem yang valid dan jumlah aitem yang gugur. Pada Skala penalaran moral dari jumlah total 30 aitem, gugur 6 aitem, sehingga tersisa 24 aitem.

Realibilitas skala gaya pengasuhan dengan pendekatan belah dua, komputasi koefisien alpha terhadap data dari 81 orang siswa adalah gaya pengasuhan otoriter $=0.6662$, gaya pengasuhan otoritatif $=0.6920$ dan gaya pengasuhan permissif $=0.7223$.

Analisis data dalam penelitian ini dilakukan dengan analisis perbandingan ganda (Multiple Comparison Analysis) dan uji two ways ANOVA. Keseluruhan komputasi data dilakukan dengan program Statistical Package for Social Science (SPSS) for Windows Release 11.0 .

Setelah memperoleh data penelitian yang dibutuhkan, dilakukan uji asumsi untuk mengetahui apakah data memenuhi syarat untuk analisis selanjutnya untuk menguji hipotesis penelitian. Uji asumsi yang perlu dilakukan adalah uji normalitas dan uji homogenitas, keduanya dianalisis dengan menggunakan program SPSS 11.0 for Windows.

\section{Hasil Penelitian dan Diskusi}

Berdasarkan hasil uji statistik untuk normalitas data penalaran moral berdasarkan gaya pengasuhan, diperoleh nilai signifikansi gaya pengasuhan otoriter sebesar 0.274, nilai signifikansi gaya pengasuhan otoritatif sebesar 0.704 dan nilai signifikansi gaya pengasuhan permisif sebesar 0.104 . Oleh karena nilai signifikansi dari ketiga gaya pengasuhan di atas $>0.05=\mathrm{a}$, maka H0 tidak ditolak berarti data berdistribusi normal.

Test of Normality

\begin{tabular}{|c|c|c|c|c|c|c|}
\hline \multirow[t]{2}{*}{$\begin{array}{l}\text { Pola } \\
\text { Asuh }\end{array}$} & \multicolumn{3}{|c|}{$\begin{array}{l}\text { Kolmogorof- } \\
\text { Smirnov }^{a}\end{array}$} & \multicolumn{3}{|c|}{ Shapiro-Wilk } \\
\hline & Statistic & $\mathrm{df}$ & Sig. & Statistic & df & Sig. \\
\hline PMA & & & & & & \\
\hline Otoriter & .201 & 8 & $.200 *$ & .897 & 8 & .274 \\
\hline Otoritatif & .094 & 38 & $.200 *$ & .980 & 38 & .704 \\
\hline Permisif & .109 & 35 & $.200 *$ & .949 & 35 & .104 \\
\hline
\end{tabular}

*. This is a lower bound of the true significance

a. Lilliefors significance correction

Selanjutnya berdasarkan hasil uji statistik untuk normalitas data penalaran moral berdasarkan jenis kelamin, diperoleh nilai signifikansi penalaran moral siswa laki-laki sebesar 0.157 dan nilai signifikansi penalaran moral siswa perempuan sebesar 0.141. Oleh karena nilai signifikansi data penalaran moral dari kedua jenis kelamin berada di atas $>0.05$ 
= a, maka H0 tidak ditolak berarti data penalaran moral dari kedua jenis kelamin juga berdistribusi normal.

Uji homogenitas adalah suatu pengujian distribusi sebaran skor variable untuk melihat apakah subjek yang telah diambil memiliki varians yang sama (homogen). Uji homogenitas dilakukan dengan menggunakan program uji Lilliefors. Hasil dari pengujian yang diperoleh menunjukkan bahwa data penalaran moral subjek berdasarkan skor rata-rata gaya pengasuhan diperoleh nilai signifikasi atau $\mathrm{P}=0.100>0.05=$ ?, maka Ho tidak ditolak berarti variansi datanya homogen atau memiliki varians yang sama. Selain itu, data penalaran moral subjek berdasarkan jenis kelamin, diperoleh nilai signifikansi $0.358>0.05=$ ?, maka Ho tidak ditolak berarti variansi datanya juga homogen.

\begin{tabular}{lcccccc}
\multicolumn{9}{c}{ Test of Normality } \\
\hline KK & \multicolumn{3}{c}{$\begin{array}{c} \\
\text { Kolmogorof- } \\
\text { Smirnov }\end{array}$} & \multicolumn{3}{c}{ Shapiro-Wilk } \\
\cline { 2 - 7 } & Statistic & df & Sig. & Statistic & df & Sig. \\
\hline PMA & & & & & & \\
& .133 & 35 & .122 & .955 & 35 & .157 \\
$\begin{array}{l}\text { Laki-laki } \\
\text { perempuan }\end{array}$ & .070 & 46 & $.200^{*}$ & .962 & 46 & .141 \\
& & & & & &
\end{tabular}

*. This is a lower bound of the true significance

a. Lilliefors significance correction

\begin{tabular}{lllll}
\hline & $\begin{array}{l}\text { Levene } \\
\text { Statistic }\end{array}$ & df1 & df2 & Sig. \\
\hline PMA & & & & \\
\hline Based on Mean & .855 & 1 & 79 & .358 \\
\hline Base on Median & .873 & 1 & 79 & .353 \\
\hline $\begin{array}{l}\text { Base on Median } \\
\text { and with }\end{array}$ & .873 & 1 & 75.115 & .353 \\
$\begin{array}{l}\text { adjusted df } \\
\text { Based on } \\
\text { trimmed mean }\end{array}$ & .795 & 1 & 79 & .375 \\
\hline
\end{tabular}

Rerata penalaran moral siswa laki-laki berinteligensi tinggi yang memperoleh gaya pengasuhan otoriter sebesar 69.00, gaya pengasuh

an otoritatif sebesar 83.87 dan gaya pengasuhan permisif sebesar 80,33. Sedangkan rerata penalaran moral siswa perempuan yang memperoleh gaya pengasuhan otoriter sebesar 91.67, gaya pengasuhan otoritatif sebesar 82.17 dan gaya pengasuhan permisif sebesar 77.80.

Interaksi pola asuh dan jenis kelamin dalam mempengaruhi skor penlaran moral

Test of between subject effect

\begin{tabular}{lcccrr}
\hline \multicolumn{1}{c}{ Source } & $\begin{array}{c}\text { Type III } \\
\text { Sum } \\
\text { of } \\
\text { Squares }\end{array}$ & $\begin{array}{c}\text { d } \\
\mathbf{f}\end{array}$ & $\begin{array}{c}\text { Mean } \\
\text { Square }\end{array}$ & F & Sig \\
\hline $\begin{array}{l}\text { Corrected } \\
\text { Model }\end{array}$ & $1415.120^{\mathrm{a}}$ & 5 & 283.024 & 3.029 & .01 \\
\hline Intercept & 309244.1 & 1 & 309244.1 & 3309.43 & .00 \\
\hline Polaasuh & 279.656 & 2 & 139.828 & 1.496 & .23 \\
& & & & & 1 \\
\hline JK & 447.355 & 1 & 447.355 & 4.787 & .03 \\
\hline Polaasuh*J & 1042.855 & 2 & 521.427 & 5.580 & .00 \\
K & & & & & 6 \\
\hline Error & 7008.238 & 7 & 93.443 & & \\
\hline Total & 534693.0 & 8 & & & \\
\hline Corrected & 8423.358 & 8 & & & \\
Total & & 0 & & & \\
\hline
\end{tabular}

Berdasarkan perhitungan statistik melalui teknik Analisis varians dua arah, diperoleh hasil penalaran moral berdasarkan faktor gaya pengasuhan dan jenis kelamin dengan nilai signifikansi $0.006<0.05=$ ?, maka Ho ditolak berarti ada interaksi antara faktor gaya pengasuhan dan jenis kelamin terhadap penalaran moral anak laki-laki dan anak perempuan. Dengan kata lain, interaksi gaya pengasuhan dan jenis kelamin berpengaruh terhadap skor penalaran moral anak laki-laki dan anak perempuan. 
Berdasarkan jenis kelamin perempuan

Dependent variable PMA

Scheffe

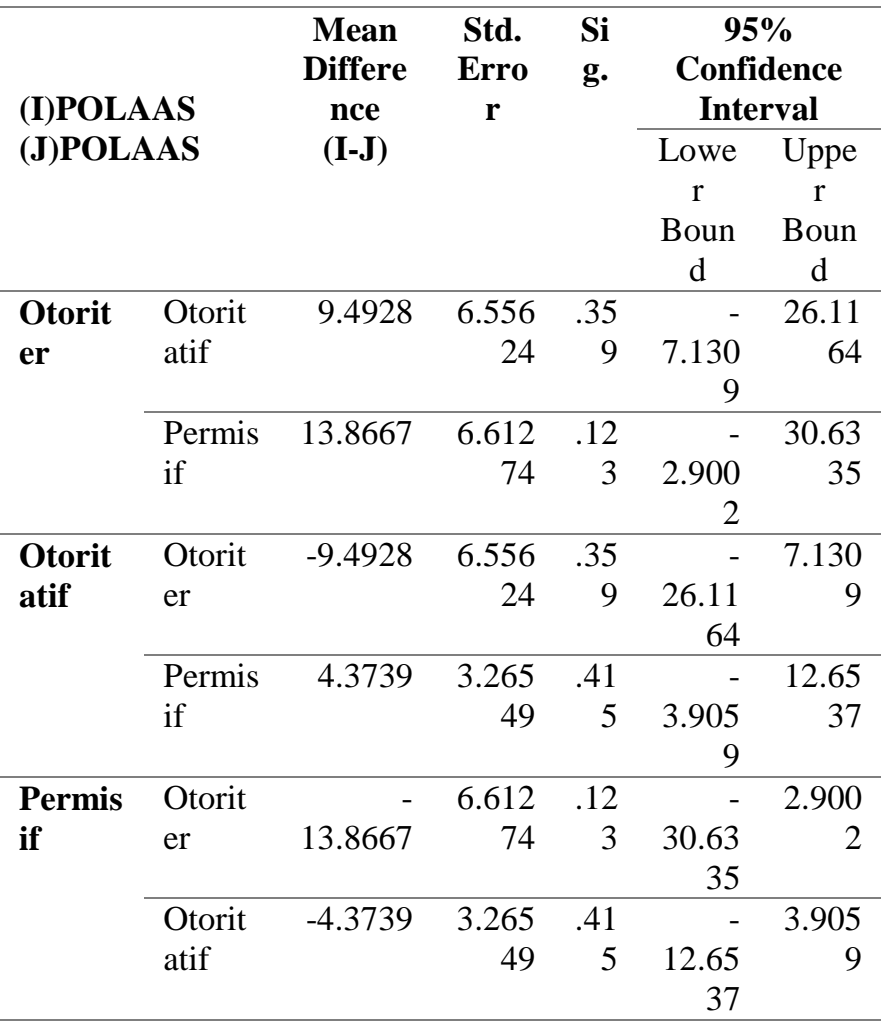

Penalaran moral anak laki-laki dan anak perempuan, berdasarkan adanya interaksi antara gaya pengasuhan dengan jenis kelamin menunjukkan bahwa tidak ada perbedaan penalaran moral siswa lakilaki yang memperoleh gaya pengasuhan otoriter dibandingkan dengan siswa yang memperoleh gaya pengasuhan otoritatif, demikian juga antara siswa laki-laki yang memperoleh gaya pengasuhan otoriter dibandingkan dengan siswa yang memperoleh gaya pengasuhan permisif juga menunjukkan tidak ada perbedaan. Namun demikian, antara siswa laki-laki yang memperoleh gaya pengasuhan otoritatif dibandingkan dengan siswa lakilaki yang memperoleh gaya pengasuhan permisif menunjukkan ada perbedaan penalaran moral yang signifikan.

Penalaran moral berdasarkan gaya pengasuhan bagi siswa perempuan menunjukkan bahwa tidak ada perbedaan penalaran moral yang signifikan antara siswa yang memperoleh gaya pengasuhan otoriter dibandingkan dengan siswa yang memperoleh gaya pengasuhan otoritatif. Demikian juga antara siswa perempuan yang memperoleh gaya pengasuhan otoritatif dibandingkan dengan siswa perempuan yang memperoleh gaya pengasuhan permisif tidak menunjukkan adanya perbedaan penalaran moral yang signifikan dan antara siswa perempuan yang memperoleh gaya pengasuhan otoriter dibandingkan dengan siswa yang memperoleh gaya pengasuhan permisif tidak menunjukkan adanya perbedaan penalaran moral. Dengan demikian perbedaan penalaran moral ditemukan pada gaya pengasuhan otoritatif dan gaya pengasuhan permisif yang diperoleh anak laki-laki dan anak perempuan, yakni ada perbedaan penalaran moral pada anak lakilaki tetapi tidak ada perbedaan penalaran moral pada anak perempuan. Perbedaannya dapat dilihat dari rerata penalaran moral anak laki-laki yang memperoleh gaya pengasuhan otoritatif sebesar 83,87 dan rerata penalaran moral anak laki-laki yang memperoleh gaya pengasuhan gaya pengasuhan permisif sebesar 80,33, sedangkan rerata penalaran moral anak perempuan yang memperoleh gaya pengasuhan otoritatif sebesar 81,17 dan penalaran moral anak perempuan yang memperoleh gaya pengasuhan permisif sebesar 77,80.

Hal ini berarti bahwa penalaran moral anak laki-laki yang memperoleh gaya pengasuhan otoritatif lebih tinggi daripada penalaran moral anak perempuan yang memperoleh gaya pengasuhan otoritatif, demikian juga penalaran moral anak lakilaki yang memperoleh gaya pengasuhan permisif lebih tinggi daripada penalaran moral anak perempuan yang memperoleh gaya pengasuhan permisif. Dengan demikian asumsi adanya perbedaan penalaran moral anak laki-laki dan anak perempuan ditinjau dari gaya pengasuhan orang tua telah dibuktikan.

Gaya pengasuhan dan jenis kelamin telah terbukti saling berinteraksi dalam mempengaruhi penalaran moral anak. 
Hasil penelitian menunjukkan bahwa anak laki-laki yang memperoleh pola asuh otoritatif menunjukkan penalaran moral yang lebih tinggi dan anak laki-laki yang memperoleh pola asuh otoriter menunjukkan penalaran moral yang paling rendah. Sedangkan pada anak perempuan yang memperoleh pola asuh otoriter menunjukkan penalaran moral yang sedikit lebih tinggi dibandingkan anak perempuan yang memperoleh pola asuh otoritatif dan permisif.

Melalui gaya pengasuhan otoritatif, anak belajar memahami sendiri batasanbatasan moral yang harus dipegangnya tanpa merasa dikekang. Pengasuhan otoritatif membantunya menumbuhkan keyakinan dan kepercayaan diri serta mendorong tindakan-tindakan mandiri membuat keputusan sendiri sehingga berakibat munculnya tingkah laku mandiri yang bertanggung jawab. Beda halnya jika anak memperoleh gaya pengasuhan permisif, dimana orang tua cenderung selalu memberikan kebebasan pada anak tanpa memberikan kontrol sama sekali. Anak diberikan kesempatan sebebasbebasnya untuk berbuat dan memenuhi keinginannya. Hal ini akan membuat anak merasa tidak digubris atau tidak diperdulikan seluruh perbuatannya maka ia akan mencari perhatian dengan cara menampilkan perbuatan yang negatif yang dapat mencemarkan nama baik keluarganya. Jika tindakan negatif mendapat penguatan maka anak akan lebih sering melakukan tindakan yang negatif. Hal ini sejalan dengan hasil penelitian ini dimana anak baik laki-laki maupun perempuan yang memperoleh gaya pengasuhan otoritatif dan gaya pengasuhan permisif menunjukkan adanya perbedaan penalaran moral, dimana anak laki-laki dan anak perempuan yang memperoleh gaya pengasuhan otoritatif memiliki penalaran moral yang lebih tinggi daripada anak laki-laki dan anak perempuan yang memperoleh gaya pengasuhan permisif.
Tidak adanya perbedaan penalaran moral pada anak laki-laki dan perempuan baik yang diasuh dengan gaya pengasuhan otoriter maupun gaya pengasuhan permisif dimungkinkan karena gaya pengasuhan otoriter memang membatasi hak anak tetapi tetap menuntut tanggung jawab seperti anak dewasa, memaksa anak-anak untuk patuh pada nilai-nilai orang tua, serta mencoba membentuk tingkah laku anak sesuai dengan tingkah laku orang tuanya akan mengakibatkan anak merasa terkekang dan dibatasi keinginan dan hasratnya yang besar untuk untuk mencari nilai-nilai baru yang kemungkinan bertolak belakang dengan norma-norma masyarakat yang sudah mapan.

Tidak adanya perbedaan penalaran moral pada anak laki-laki dan anak perempuan antara yang memperoleh gaya pengasuhan otoriter dibandingkan yang memperoleh gaya pengasuhan otoritatif dimungkinkan karena gaya pengasuhan otoriter merupakan cara melatih dan mengatur anak laki-laki untuk terlibat dan mendekat secara fisik walaupun menekankan dominasi orang dewasa. Menurut Greenfield \& Suzuki (dalam Berns 2004), kondisi-kondisi tertentu seperti kondisi lingkungan sekitar anak yang dianggap berbahaya mendorong orang tua untuk memberikan disiplin yang keras bukan untuk mendominasi tetapi untuk menjaga dan melindungi integritasnya, melindungi, serta menjaga hubungan yang harmonis dengan orang lain serta agar anak laki-laki tidak terjebak dalam aktivitas-aktivitas anti sosial atau merusak moral. Sedangkan gaya pengasuhan otoritatif akan memotivasi anak laki-laki untuk belajar dan berperilaku menurut harapan-harapan orang tua, yang pada akhirnya dapat mempengaruhi anak di dalam mengambil suatu keputusan atau di dalam melakukan penalaran moral.

Tidak adanya perbedaan penalaran pada anak perempuan yang memperoleh gaya pengasuhan otoriter dibandingkan dengan anak perempuan yang memperoleh 
gaya pengasuhan otoritatif dimungkinkan karena bahwa emosi perempuan lebih besar daripada anak laki-laki dan anak perempuan kurang tegas atau mudah bimbang dan memiliki kecemasan (Archer, 1996). Anak perempuan memiliki respon emosi yang berbeda dengan anak laki-laki ketika mengalami ketegangan. Menurut Campbell (1993 dalam Chesney, 2004), rasa marah pada anak perempuan disertai emosi-emosi seperti rasa takut, cemas, merasa bersalah dan rasa malu; sedangkan rasa marah pada anak laki-laki ditandai dengan amukan atau menentang nilai-nilai moral. Anak perempuan ketika marah cenderung menyalahkan diri sendiri karena mereka khawatir kemarahannya akan membahayakan orang lain dan merusak hubungan dengan orang lain. Orang tua otoritatif yang menunjukkan sikap simpatik, hangat dan mendukung akan membantu anak perempuan agar dapat mengatur emosi secara efektif sehingga termotivasi untuk belajar dan berperilaku menurut harapan-harapan orang tua sehingga mampu membuat keputusan moral dengan baik.

Hal ini sesuai pernyataan Mathias (1987), ketika melakukan penalaran moral, anak berpikir mengenai soal-soal moral berdasarkan motivasi yang ada di dalam diri individu yang kemudian dituangkan ke dalam bentuk pilihan di dalam melakukan penalaran moral. Orang tua otoriter yang cenderung keras dan sering menerapkan disiplin yang keras, bagi anak perempuan yang sensitifitas emosinya tinggi akan membuat anak perempuan menyimpan perasaannya dan keinginannya padahal ketika orangtua memberikan tuntutan dan harapan seharusnya memberikan penawaran alasan atau pembenaran sehingga menyebabkan anak perempuan tidak mengalami lebih banyak konflik sosio kognitif yang pada gilirannya berpengaruh terhadap perkembangan penalaran moralnya.

Beberapa alasan mengapa penerapan disiplin orang tua dalam gaya pengasuhannya memiliki hubungan dengan perkembangan moral berbeda berdasarkan gender anak. Pertama, anak laki-laki dan perempuan berbeda pada seluruh tingkatan internalisasi moral. Contoh, sejak masa kanak-kanak awal, anak perempuan menunjukkan tingkatan yang lebih tinggi dari rasa bersalah, empati dan kematangan kognitif sosial, semuanya memiliki hubungan konseptual dengan perkembangan moral. Kedua, orang tua menggunakan tipe dan atau tingkat disiplin yang berbeda untuk anak laki-laki dan perempuan sehingga akan mempengaruhi internalisasi anak-anak terhadap pesan-pesan dan ungkapan orang tua tentang perilaku moral. Ketiga, hubungan antara beberapa tipe disiplin orang tua dan dampaknya pada anak diperantarai oleh gender anak (David dan Nestor, 2004).

Bagi anak yang tidak didukung oleh lingkungan sosial sebenarnya bukan sesuatu yang mudah, apalagi subjek dalam penelitian ini lahir dan dibesarkan dalam masyarakat Jawa yang lebih mengutamakan kepatuhan dan kesopanan pada seorang anak, atau menolak spontanitas dalam mengungkapkan diri karena dianggap tidak etis. Koentjaraningkat (1999 dalam Widyorini) bahwa dalam masyarakat Jawa mengutamakan tingkah laku dan adat sopan santun terhadap orang tua. Dalam budaya Jawa antara laki-laki dan perempuan mendapat perlakuan dan tuntutan yang berbeda secara cukup menyolok. Keluarga Jawa mempunyai pandangan dan harapan yang berbeda pada anak laki-laki dan perempuan. Pembagian peran berhubungan dengan hal-hal apa yang boleh dilakukan dan siapa yang boleh melakukan mempengaruhi pemahaman mengenai partisipasi masingmasing jenis kelamin dalam kehidupan bermasyarakat. Dengan demikian ketika terjadi suatu ketidakseimbangan peran yang diperoleh dari status antara anak lakilaki dan anak perempuan, pada akhirnya akan mempengaruhi kognitif yang berbeda antara anak laki-laki dan anak perempuan 
yang pada akhirnya berpengaruh terhadap perkembangan penalaran moralnya.

Tidak adanya perbedaan penalaran pada anak perempuan yang memperoleh gaya pengasuhan otoriter dibandingkan dengan anak perempuan yang memperoleh gaya pengasuhan otoritatif dimungkinkan karena bahwa emosi perempuan lebih besar daripada anak laki-laki dan anak perempuan kurang tegas atau mudah bimbang dan memiliki kecemasan (Archer, 1996). Anak perempuan memiliki respon emosi yang berbeda dengan anak laki-laki ketika mengalami ketegangan. Menurut Campbell (1993 dalam Chesney, 2004), rasa marah pada anak perempuan disertai emosi-emosi seperti rasa takut, cemas, merasa bersalah dan rasa malu; sedangkan rasa marah pada anak laki-laki ditandai dengan amukan atau menentang nilai-nilai moral. Anak perempuan ketika marah cenderung menyalahkan diri sendiri karena mereka khawatir kemarahannya akan membahayakan orang lain dan merusak hubungan dengan orang lain.

Orang tua otoritatif yang menunjukkan sikap simpatik, hangat dan mendukung akan membantu anak perempuan agar dapat mengatur emosi secara efektif sehingga termotivasi untuk belajar dan berperilaku menurut harapanharapan orang tua sehingga mampu membuat keputusan moral dengan baik. Hal ini sesuai pernyataan Mathias (1987), ketika melakukan penalaran moral, anak berpikir mengenai soal-soal moral berdasarkan motivasi yang ada di dalam diri individu yang kemudian dituangkan ke dalam bentuk pilihan di dalam melakukan penalaran moral. Sebaliknya orang tua otoriter yang cenderung keras dan sering menerapkan disiplin yang keras, bagi anak perempuan yang sensitifitas emosinya tinggi akan membuat anak perempuan menyimpan perasaannya dan keinginannya padahal ketika orangtua memberikan tuntutan dan harapan seharusnya memberikan penawaran alasan atau pembenaran sehingga menyebabkan anak perempuan beresiko mengalami lebih banyak konflik sosio kognitif yang pada gilirannya berpengaruh terhadap perkembangan penalaran moralnya.

Gaya pengasuhan orang tua berpengaruh terhadap penalaran moral siswa laki-laki dan perempuan. Hal ini sejalan dengan salah satu perspektif teoritis utama tentang perbedaan jenis kelamin dalam membentuk perilaku, yaitu perspektif teori proses belajar yang menekankan adanya proses dalam pembentukan perilaku seperti penguatan dan peniruan seseorang memperoleh ciriciri menetap yang berkaitan dengan jenis kelamin (Sears, 1994).

Orang tua melalui tindakan dan contoh mempengaruhi anak laki-laki dan perempuan untuk menyesuaikan diri dengan norma-norma moral yang ada dalam lingkungan budayanya. Sinyalsinyal perlakuan yang bertujuan untuk membedakan antara laki-laki dan perempuan dalam masyarakat sesungguhnya telah ada, yang kemudian meresap sejak mereka kanak-kanak, bahwa ia laki-laki maka ia harus begini dan karena ia perempuan ia harus begitu.

Perbedaan perlakuan berdasarkan gender ini menjadi norma sejak usia dini, yang selanjutnya menjadi lebih kuat dan nyata di dalam kehidupan sosial. Terjadinya perubahan-perubahan psikologis pada siswa perempuan ini sebagai akibat dari adanya konflik antara kebutuhan psikologis dengan pengharapan masyarakat terhadap peran gender, anak perempuan sejak kecil belajar dari keluarganya, sekolah, dan media massa mengenai perilaku yang dapat diterima kelompok (keluarga, sekolah, dan masyarakat), dan anak perempuan juga mempelajari hal-hal yang ditolak kelompoknya, dan ia berusaha untuk menghindarinya (Klein, 1996; Leroux, 1992 dalam Widyorini, 1992).

Orang tua memiliki kecenderungan bertindak berbeda terhadap anak laki-laki dan perempuan dalam berperilaku yang sesuai dengan nilai moral yang berlaku dalam masyarakatnya, dimana ketika 
menerapkan gaya pengasuhan orang tua memiliki harapan-harapan perilaku tertentu menurut jenis kelamin anaknya sehingga memungkinkan anak laki-laki dan perempuan mendapatkan kesempatan alih peran yang berbeda di dalam pembelajaran moral. Hal ini sejalan dengan teori belajar sosial bahwa anakanak belajar bersikap dan berperilaku yang sesuai dan tidak sesuai dengan perilaku gender melalui observasi dan peniruan dari perbedaan perlakuan orang tua terhadap anak laki-laki dan perempuan.

Suatu lingkungan tertentu akan memiliki pengaruh yang berbeda tergantung pada kecenderungankecenderungan anak laki-laki dan perempuan dalam membangun versi mereka sendiri tentang pola -pola perilaku secara aktif. Gaya orangtua di dalam mensosialisasikan dan menerapkan pembelajaran moral pada anak laki-laki dan perempuan dalam kondisi tertentu mendukung terjadinya perbedaan perkembangan penalaran moral antara anak laki-laki dan perempuan. Beberapa alasan mengapa penerapan disiplin orang tua dalam gaya pengasuhannya memiliki hubungan dengan perkembangan moral berbeda berdasarkan gender anak. Pertama, anak laki-laki dan perempuan berbeda pada seluruh tingkatan internalisasi moral. Contoh, sejak masa kanak-kanak awal, anak perempuan menunjukkan tingkatan yang lebih tinggi dari rasa bersalah, empati dan kematangan kognitif sosial, semuanya memiliki hubungan konseptual dengan perkembangan moral. Kedua, orang tua menggunakan tipe dan atau tingkat disiplin yang berbeda untuk anak laki-laki dan perempuan sehingga akan mempengaruhi internalisasi anak-anak terhadap pesan-pesan dan ungkapan orang tua tentang perilaku moral. Ketiga, hubungan antara beberapa tipe disiplin orang tua dan dampaknya pada anak diperantarai oleh gender anak (David dan Nestor, 2004).
Greenfield \& Suzuki (dalam Berns 2004), kondisi-kondisi tertentu seperti kondisi lingkungan sekitar anak yang berbahaya mendorong orang tua untuk memberikan disiplin yang keras untuk melindungi anak perempuan agar tidak terjebak dalam aktivitas-aktivitas anti sosial. Eron dkk (dalam Stewart dan Koch, 1983) mengatakan bahwa anak perempuan cenderung mengidentifikasikan orang dewasa ke dalam dirinya. Pada anak perempuan ketakutan dihukum orangtua lebih menguasai dirinya, tetapi anak yang tidak mengidentifikasikan dirinya pada orangtua dikarenakan mereka tidak mau mengimitasi apa yang dikatakan dan dikerjakan oleh orangtua mereka.

Pembagian peran berhubungan dengan hal-hal apa yang boleh dilakukan dan siapa yang boleh melakukan mempengaruhi pemahaman mengenai partisipasi masing-masing jenis kelamin dalam kehidupan bermasyarakat. Dengan demikian ketika terjadi suatu ketidakseimbangan peran yang diperoleh dari status antara anak laki-laki dan anak perempuan, pada akhirnya akan mempengaruhi kognitif yang berbeda antara anak laki-laki dan anak perempuan yang pada akhirnya berpengaruh terhadap perkembangan penalaran moralnya.

\section{Kesimpulan}

Telah dibuktikan bahwa pola asuh dan jenis kelamin saling berinteraksi dalam mempengaruhi penalaran moral anak. Ada perbedaan penalaran moral antara laki-laki dan perempuan yang memperoleh pola asuh otoriter, otoritatif dan permisif.

Dengan hasil penelitian yang di dapat tersebut, disarankan bagi pendidik hendaknya mengembangkan strategi mengajar yang tepat yang dapat mengembangkan aspek positif bagi anak dengan (a) menghindari stereotip peran jenis kelamin; (b) memberi dorongan bagi anak laki-laki dan perempuan untuk independen dan berani mengambil resiko; (c) membimbing mereka dalam perilaku problem solving dan strategi pengambilan 
keputusan. Bagi orang tua, hendaknya hendaknya menghindarkan pola pengasuhan atau tuntutan (harapan) yang berbeda bagi anak laki-laki dan perempuan dan membantu mereka menetapkan batasan-batasan dalam membuat keputusan moral secara tepat sehingga anak terhindar dari masalah penyesuaian sosial.

\section{Daftar Pustaka}

Archer, J. (1996). Sex Differences in Social Behavior : are the social role and evolutionary explanations compatible. American Psychological Association, Vol. 51 (9) : 909-91.

Bee, H. (1997). The Developing Child. New York: Harper \& Row Publisher

Berndt, Thomas J. (1992). Child Development. Florida: Rinehart \& Winston Inc.

Berns, R.B. (2004). Child, Family, School and Community : socialization and support. Belmont : Thomson Learning Inc.

Bjourklund. (2005). Children's Thinking : cognitive development and individual differences. New York : Jhon Willey and Son Inc

Budiningsih, C. Asri. (2004). Pembelajaran moral berpijak pada karakteristik siswa dan budayanya. Jakarta : PT. Asdi Mahasatya.

Crain, William. (2014). Teori Perkembangan : konsep dan aplikasi. Jakarta : Pustaka Pelajar

Chesney, Meda., Lind, Pasko, Lisa. (2004). Girls, Women And Crime, London : Sage Publication.

David C. R., Nestor L. Lopez. 2004. Parental Discipline and Externalizing Behavior Problems in Childhood : the Roles of Moral Regulation and Child Gender. Journal of Abnormal Child Psychology, Vol. 32, (4) : 369-383
Deleeuw, N. S. (2002). Gifted Preschoolers: Parent and Teacher View on Identification, Early Admission and Programming, Rooper Review, 21 (3) : 174-179

Derscheid, L.E. (2010). Mixed-age Grouped Preschoolers' Moral Behavior and Understanding. Journal of Research in Childhood Education, 11 : 147- 151

Harjaningrum, Agnes Tri, et al., (2007). Peranan Orang Tua dan Praktisi dalam Membantu Tumbuh Kembang Anak Berbakat melalui pemahaman teori dan tren Pendidikan. Jakarta : Prenada Media Group

Kohlberg, L. (1981). The Philosophy of Moral Development, Moral Stages, and Idea of Justice. San Francisco : Harper \& Row Publisher

Oemardi, K.A.(2004). Pendekatan Cognitive Behavior dalam Psikoterapi. Jakarta: Kreatif Media

Sears, David O., Freedman, Jonathan L. (1994). Psikologi Sosial, Jilid 2. Alih bahasa : Michael Adriyanto, Jakarta : Erlangga

Sopiatin, Popi., Sahrani, Sohari. (2011). Psikologi Belajar dalam persfektif Islam, Bogor: Ghalia Indonesia.

Taher, Thahroni. (2013). Psikologi Pembelajaran Pendidikan Agama Islam, Jakarta : Rajawali Pers

Tirtonogoro, Sutratinah, (2010) Anak Supernormal Dan Program Pendidikanya. Jakarta : PT. Bumi Aksara

Walker, L. J. \& Hennic, K. H. (1999), Parenting Style and the Development of Moral Reasoning Journal of Moral Education, 28 (3) : 360-374

Widyorini, Endang, (2004), Perempuan Berbakat Dalam Budaya Jawa. Tesis. Yogyakarta : Universitas Gajah Mada Zuchdi, Darmiyati. Humanisasi Pendidikan: Menemukan Kembali Pendidikan yang Manusiawi. Jakarta : Bumi Aksara 